\title{
Effect of Integrated Nutrient Management Practices on Soil Biological Properties in Acid Lime (Citrus aurentifolia Swingle) Orchard
}

\author{
U.B. Deshmukh ${ }^{1}$, N.K. Mishra ${ }^{1 *}$ and S.G. Bharad ${ }^{2}$ \\ ${ }^{1}$ Indira Gandhi Krishi Vishwavidyalaya, College of Agriculture and Research Station, \\ Korea, Chhattisgarh-497335, India \\ ${ }^{2}$ Department of Horticulture, Dr. Panjab Rao Deshmukh Krishi Vishwavidyalya, Akola, \\ Maharashtra-444001, India \\ *Corresponding author
}

\section{A B S T R A C T}

\section{Keywords}

Nutrient, Soil,

Biological properties, Acid lime

Article Info

Accepted:

07 March 2018

Available Online:

10 April 2018
The present investigation deals with the effect of integrated nutrient management practices on soil biological properties in an established orchard of acid lime (Citrus aurentifolia Swingle). The experiment was undertaken with eleven treatments (T) including a control in randomized block design at PDKV, Akola, Maharastra during two growing seasons of 2010-11 and 2011-12. The observations were recorded for different soil biological properties such as, soil microbial count, soil microbial biomass carbon, dehydrogenase activity, $\mathrm{CO}_{2}$ evolution, Organic carbon. Among the treatments, ' $\mathrm{T}_{8}$ ' $(75 \% \mathrm{RDF}$ $(450: 225: 225 \mathrm{~g} \mathrm{NPK})+50 \mathrm{Kg}$ FYM $+500 \mathrm{~g} \mathrm{AM} /$ Plant $+100 \mathrm{~g} \mathrm{PSB} \mathrm{/Plant+200g}$ $\mathrm{ZnSO}_{4} /$ plant $)$ followed by treatment ' $\mathrm{T}_{10}$ ' $(75 \% \mathrm{RDF}(450: 225: 225 \mathrm{~g} \mathrm{NPK})+50 \mathrm{Kg}$ FYM+100g Azospirillum $+100 \mathrm{~g}$ PSB /Plant+200g ZnSO $4 /$ plant) showed significant variation as compared to other treatments studied. So, treatments $T_{8}$ and $T_{10}$ are recommended to be followed in acid lime cultivation for better growth and development.

\section{Introduction}

Acid lime (Citrus aurentifolia Swingle) is originated in India and belongs to family Rutaceae. It contributed to more than 11 percent of world fruit production and ranks second in world with an annual production of 63.83 million tons from an area of 8.46 million ha (Anonymous, 2011). Citrus is considered as a highly nutrient-responsive perennial fruit crop (Srivastava, 2008). A wide gap still exists between domestic demand and supply for fruits and this gap can be bridged by increasing productivity at least equal to the extent possible through area expansion. India's fruit requirement for 2025 is estimated to be 120 MT (Tiwari, 2015). These production and productivity targets will be achieved through modern intensive horticulture practices and use of most recent technologies, including nutrient management. Conventional methods of fertilization although helped in improving the fruit quality but continuous fertilization, has failed to sustain the same yield on a long-term basis due to depletion of soil carbon stock and consequently emerged multiple nutrient deficiencies, would be further triggered 
through changes in microbial communities and activities within the rhizosphere (Patel et al., 2009). Such changes will adversely affect the orchard's productive life in the long run. Integrated nutrient management is a holistic approach which maintains the soil fertility and nutrient supply to an optimum level for sustaining the desired crop productivity (Chundawat, 2001).

Integrated use of nutrient supplements viz., organic, inorganic, biofertilizers and micronutrient holds a good potential to overcome most of soil physical, chemical and biological constraints (Patel et. al. 2009). Organic manure applied to soil, improve the soil physical properties and add important nutrients to the soil increase the availability and its ultimate absorption by plant. Biofertilizer like Azospirillum, VAM and PSB fix major nutrients in soil. The application organic manure and biofertilizers help in better utilization of added inorganic fertilizers and reduce its application level as well as the deleterious effect of harsh chemical fertilizers use (Dheware and Waghmare, 2009). Keeping in view the present investigation was carried out to testify the effect of integrated nutrient management practices on soil biological properties in an established acid lime orchard.

\section{Materials and Methods}

The experiment conducted in a 10 years old established orchard of acid lime cv. PDKV lime situated at Shivar Block, Central Research Station, Akola, Maharastra. The experiment consisted of eleven treatments including a control with three replications (Table 1). One plant from each treatment was selected, marked and kept under continuous observation for two years during 2010-11 and 2011-12. The data was recorded on a number of soil biological properties such as soil microbial count, soil microbial biomass carbon, Dehydrogenase activity, $\mathrm{CO}_{2}$ evolution and organic carbon. Soil microbial biomass carbon was determined by chloroform fumigation method as described by Jenkison and Powlson (1976), dehydroginase activity by Klein et al., (1971) and $\mathrm{CO}_{2}$ evaluation of soil determined by alkali trap method of Anderson (1982). Organic carbon calculated by using method suggested by Walkely and Black (Nelson and Sommer, 1982). Serial dilution plate technique was used for counting and isolation of soil microbial populations. Statistical analysis was done as per Panse and Sukhatme (1967).

\section{Results and Discussion}

Microbial population in soil rhizosphere improved after application of different treatments (Table 1). During first season (2010-11), the highest soil fungi microbes was recorded in treatment $T_{8}$ which at par with $T_{5}$ while, in second season (2011-12) soil fungi microbes was recorded highest in $\mathrm{T}_{7}$ which at par with $\mathrm{T}_{8}$, and $\mathrm{T}_{4}$. In case of soil bacterial microbes the maximum population was recorded in $\mathrm{T}_{10}$ which at par with $\mathrm{T}_{9}$. The highest soil actinomycetes were recorded in same treatment i.e., $\mathrm{T}_{8}$ in both the seasons which at par with $\mathrm{T}_{9}, \mathrm{~T}_{10}$ and $\mathrm{T}_{7}$. These results are in accordance with the findings of Srivastava et al., (2008) in citrus, Dutta et al., (2010) in litchi, Marathe et al., (2012) in sweet orange, Majhi and Rout (2016) in rice. Dehydrogenase activity was recorded highest in $\mathrm{T}_{10}$ in first season (2010-11) which at par with $\mathrm{T}_{9}, \mathrm{~T}_{7}, \mathrm{~T}_{6}$ and $\mathrm{T}_{5}$ respectively, but during second season (2011-12), maximum dehydrogenase activity was noted in $\mathrm{T}_{8}$ at par with $\mathrm{T}_{7}, \mathrm{~T}_{10}$, and $\mathrm{T}_{9}$ (Table 2). Similarly, the maximum soil microbial biomass carbon was recorded in treatment $T_{8}$ and average with $T_{10}$, $\mathrm{T}_{9}$, and $\mathrm{T} 7$ respectively, in first and second season of experiment. Whereas, $\mathrm{CO}_{2}$ evolution influenced by integrated nutrient management showed significant variation among different treatments studied. 
Table.1 Effect of integrated nutrient management on soil microbial population in acid lime

\begin{tabular}{|c|c|c|c|c|c|c|}
\hline \multirow[t]{3}{*}{ Treatment } & \multicolumn{6}{|c|}{ Microbial population ( $\left.\mathrm{cfu} \mathrm{g}^{-1}\right)$} \\
\hline & \multicolumn{2}{|c|}{ Fungi } & \multicolumn{2}{|c|}{ Bacteria } & \multicolumn{2}{|c|}{ Actinomycetes } \\
\hline & $(2010-11)$ & (2011-12) & $(2010-11)$ & (2011-12) & $(2010-11)$ & $(2011-12)$ \\
\hline $\mathrm{T}_{1}$ RDF $(600 \mathrm{gN}+300 \mathrm{~g} \mathrm{P}+300 \mathrm{~g} \mathrm{~K}+50 \mathrm{~kg}$ FYM/Plant) & 5.24 & 5.33 & 20.16 & 20.45 & 12.46 & 12.24 \\
\hline $\mathrm{T}_{2}\left(\mathrm{~T}_{1}+200 \mathrm{~g} . \mathrm{ZnS} 04 / \mathrm{Plant}\right)$ & 6.73 & 7.30 & 20.25 & 20.52 & 13.33 & 13.28 \\
\hline $\mathrm{T}_{3}(75 \%$ RDF +50kg FYM+ 500g AM/ Plant) & 7.19 & 8.23 & 21.17 & 21.48 & 14.11 & 14.44 \\
\hline $\mathrm{T}_{4}\left(\mathrm{~T}_{3}+200 \mathrm{~g} \mathrm{ZnSo} / \mathrm{Plant}\right)$ & 8.63 & 8.33 & 20.88 & 21.43 & 11.87 & 14.59 \\
\hline$T_{5}\left(T_{3}\right)+50 \mathrm{~kg}$ FYM+100gm Azospirillum & 8.70 & 7.90 & 22.43 & 22.63 & 13.55 & 14.15 \\
\hline $\mathrm{T}_{6}\left(\mathrm{~T}_{5}+200 \mathrm{~g} \mathrm{ZnSo} /\right.$ Plant $)$ & 6.45 & 7.96 & 22.63 & 22.89 & 14.19 & 13.43 \\
\hline$T_{7}\left(T_{3}+100 g\right.$ PSB/Plant $)$ & 8.45 & 9.10 & 23.05 & 24.16 & 15.40 & 15.62 \\
\hline $\mathrm{T}_{8}(\mathrm{~T} 7+200 \mathrm{~g} \mathrm{ZnSo} /$ Plant $)$ & 8.92 & 9.07 & 24.25 & 24.41 & 16.21 & 16.33 \\
\hline $\mathrm{T}_{9}(\mathrm{~T} 5+100 \mathrm{~g}$ PSB/Plant $)$ & 8.05 & 8.49 & 25.32 & 25.50 & 15.47 & 15.07 \\
\hline $\mathrm{T}_{10}\left(\mathrm{~T} 9+200 \mathrm{~g} \mathrm{ZnSo}_{4} /\right.$ Plant $)$ & 8.03 & 8.68 & 26.10 & 26.37 & 15.46 & 15.52 \\
\hline $\mathbf{T}_{11}$ (Control) & 3.18 & 3.57 & 12.15 & 12.24 & 10.36 & 10.92 \\
\hline SEm + & 0.22 & 0.31 & 0.72 & 0.68 & 0.49 & 0.57 \\
\hline CD at $5 \%$ & 0.66 & 0.93 & 2.13 & 2.01 & 1.46 & 1.67 \\
\hline
\end{tabular}

Table.2 Effect of integrated nutrient management on dehydrogenize activities, soil microbial biomass carbon, $\mathrm{CO}_{2}$ evolution and organic carbon in acid lime

\begin{tabular}{|c|c|c|c|c|c|c|c|c|}
\hline \multirow[t]{2}{*}{ Treatment } & \multicolumn{2}{|c|}{$\begin{array}{l}\text { Dehydrogenize Activity } \\
\left(\mu \mathrm{gTPF}^{-1} 24^{-1} \mathrm{hr}\right)\end{array}$} & \multicolumn{2}{|c|}{$\begin{array}{l}\text { Soil microbial biomass } \\
\left.\text { carbon( } \mu \mathrm{g} 100 \mathrm{~g}^{-1} \text { soil }\right)\end{array}$} & \multicolumn{2}{|c|}{$\begin{array}{l}\mathrm{CO}_{2} \text { Evolution } \\
\text { (mg } 100 \mathrm{~g}^{-1} \text { soil) }\end{array}$} & \multicolumn{2}{|c|}{ Organic carbon (\%) } \\
\hline & $(2010-11)$ & (2011-12) & $(2010-11)$ & (2011-12) & $(2010-11)$ & (2011-12) & $(2010-11)$ & (2011-12) \\
\hline $\mathrm{T}_{1}$ RDF $(600 \mathrm{gN}+300 \mathrm{gP}+300 \mathrm{~g} \mathrm{~K}+50 \mathrm{~kg}$ FYM/Plant) & 62.97 & 61.96 & 149.67 & 154.00 & 72.03 & 66.77 & 0.42 & 0.45 \\
\hline $\mathrm{T}_{2}\left(\mathrm{~T}_{1}+200 \mathrm{~g} \mathrm{ZnSo} 4 / \mathrm{Plant}\right)$ & 64.62 & 63.85 & 162.33 & 166.00 & 72.88 & 69.36 & 0.44 & 0.47 \\
\hline $\mathrm{T}_{3}(75 \%$ RDF +50kg FYM+ 500g AM/ Plant) & 65.17 & 62.77 & 176.67 & 180.00 & 73.67 & 72.38 & 0.46 & 0.47 \\
\hline $\mathrm{T}_{4}\left(\mathrm{~T}_{3}+200 \mathrm{~g} \mathrm{ZnSo} /\right.$ /Plant $)$ & 68.11 & 64.25 & 172.00 & 180.00 & 73.59 & 71.44 & 0.44 & 0.46 \\
\hline$T_{5}\left(T_{3}\right)+50 \mathrm{~kg}$ FYM+100gm Azospirillum & 65.99 & 66.25 & 181.33 & 179.00 & 73.65 & 71.13 & 0.45 & 0.47 \\
\hline $\mathrm{T}_{6}\left(\mathrm{~T}_{5}+200 \mathrm{~g} \mathrm{ZnSo} /\right.$ Plant $)$ & 66.87 & 67.66 & 178.67 & 178.33 & 71.33 & 71.11 & 0.46 & 0.47 \\
\hline $\mathrm{T}_{7}\left(\mathrm{~T}_{3}+100 \mathrm{~g}\right.$ PSB/Plant $)$ & 69.81 & 72.58 & 185.67 & 183.33 & 76.29 & 74.11 & 0.50 & 0.53 \\
\hline $\mathrm{T}_{8}\left(\mathrm{~T} 7+200 \mathrm{~g} \mathrm{ZnSo}_{4} /\right.$ Plant $)$ & 74.63 & 75.03 & 196.67 & 193.67 & 77.14 & 81.08 & 0.56 & 0.58 \\
\hline $\mathrm{T}_{9}(\mathrm{~T} 5+100 \mathrm{~g}$ PSB/Plant) & 75.33 & 71.22 & 190.67 & 191.67 & 76.55 & 81.40 & 0.51 & 0.54 \\
\hline $\mathrm{T}_{10}\left(\mathrm{~T} 9+200 \mathrm{~g} \mathrm{ZnSo}_{4} /\right.$ Plant $)$ & 78.21 & 72.25 & 192.67 & 193.00 & 76.77 & 76.01 & 0.54 & 0.57 \\
\hline $\mathrm{T}_{11}($ Control $)$ & 33.54 & 30.96 & 115.00 & 118.00 & 51.88 & 49.17 & 0.32 & 0.32 \\
\hline SEm \pm & 4.34 & 2.04 & 4.78 & 3.66 & 2.41 & 2.28 & 0.012 & 0.009 \\
\hline CD at $5 \%$ & 12.82 & 5.99 & 14.12 & 10.73 & 7.30 & 6.70 & 0.038 & 0.026 \\
\hline
\end{tabular}


$\mathrm{T}_{8}$ recorded maximum $\mathrm{CO}_{2}$ evolution during first season equality with all treatments, while, in second season in $\mathrm{T}_{9}$ at par with $\mathrm{T}_{8}$ and $\mathrm{T}_{10}$. In both the seasons, minimum data was recorded on all the studied parameters in $\mathrm{T}_{11}$ (control). Similar effect was also observed by Aseri et al., (2008) in pomegranate, Patel et al., (2009) in sweet orange, Suresh and Ghosal (2013) in soyabean. The maximum organic carbon was noted in $\mathrm{T}_{8}$ during first and second season of experiment which, at par with $\mathrm{T}_{10}$ during both season of experiment. Increasing organic carbon due to application of organic manures and inorganic fertilizers along with biofertilizers recorded higher organic carbon content in Sweet orange (Patel et al., 2009). Regarding this experiment of all parameters results showed significant variations under different treatments in both the seasons. So, treatments $\mathrm{T}_{8}$ and $\mathrm{T}_{10}$ are recommended to be followed in acid lime cultivation for better growth and development. However, the finding of this investigation needs to be further confirmed by long term studies for sustainable fruit production in Citrus species.

\section{References}

Anderson, J.P.E. 1982. Soil respiration, In: Page, A.L., Miller, R. H. and Keeney, D. R. (eds) Methods of soil analysis, Part 2, chemical and microbiological properties, Agronomy monograph No.9, ASA-SSSA Publishers, Madison, Wiscosin, USA. pp 831-871

Anonymous, 2011. Data Base Area and production of Horticultural fruit crops at http://www.google/nhm.com.

Aseri, G.K., Jain, N. and Meghwal, P.R. 2009. Influence of biofertilizer on Aonla establishment and production in Indian Thar desert. Indian Journal of Horticulture 66: 449-455.

Aseri, G.K., Jain, N., Rao, A.V. and Meghwal, P.R. 2008. Biofertilizers improve plant growth, fruit yield, nutrition, metabolism and rhizosphere enzyme activities of pomegranate (Punica granatum L.) in Indian Thar Desert. Scientia Horticulturae 117: 130-135.

Chundawat, B. S. 2001. Integrated nutrient management in tropical and subtropical fruits. Indian Journal of Horticulture 58: 59-69.

Dheware, R. M. and M. S. Waghmare, 2009. Influence of organic inorganic and biofertilizer and their interactions on flowering and fruitset of sweet orange (Citrus sinensis Osbeck L.). The Asian J.Hort. 4: 194-197.

Dutta, P., Kundu, S. and Biswas, S. 2010. Integrated nutrient management in Litchi cv. Bombai in new alluvial zone of West Bengal. Indian Journal of Horticulture 67:181-184.

Jenkison, D.S. and Powlson, R.A. 1976. A rapid procedure to evaluate soil microbial biomass carbon by chloroform fumigation method. Soil Biology and Biochemistry 3: 489-492.

Klein, D.A., Loh, T.C. and Goulding, R.L. 1971. A rapid procedure to evaluate dehydrogenase activity of soil low in organic matter. Soil Biology and Biochemistry 3: 385-387

Majhi, P. and Rout, K.K. 2016. Effect of continuous application of different inorganic macro and micro nutrients and FYM on crop yield and changes in soil ph and soc of an acidic typic ustochrepts typic ustochrepts under subtropical rice-rice ecosystem. The Bioscan. 11: 1813-1817.

Marathe, R.A., Bharambe, P.R., Sharma, R. and Sharma, U.C. 2012. Leaf nutrient composition, its correlation with yield and quality of sweet orange and soil microbial population as influenced by INM in vertisol of central india. Indian Journal of Horticulture 69: 317-321. 
Nelson, D.W. and Sommer, L.E. 1982. In methods of soil analysis, part II, Chemical and biological methods by Page, A.L., Miller R.H. and Keeney D.R. (eds) Agronomy Monograph No.9 $\left(2^{\text {nd }}\right.$ Edition) American Society of Agronomy and Soil Science Society of America, Madison, Wiscosin, USA: 570-572.

Panse, V.G. and Sukhatme P.V. 1967. Statistical methods for agricultural workers $2^{\text {nd }}$ enlarge edition ICAR New Delhi.

Patel, V.B., Singh, S.K., Asrey, R.L., Nain, A.K. and Singh, L. 2009. Microbial and inorganic fertilizer application influenced vegetative growth, yield, leaf nutrient status and soil microbial biomass in sweet orange cv. Mosambi. Indian Journal of Horticulture 66: 163-168.

Srivastava, A. K., A. D. Huchche., A. K. Das and Dinesh Kumar, 2008. INM method sustained productivity of citrus, NRCC Annual Report pp.3642.

Suresh, M. and Ghasolia, R.P. 2013. Effect of phosphate solubilizers and FYM on microbial population of soybean field [Glycine max (L.) merrill]. The Bioscan. 8: 965-968.

Tiwari, K.N. 2015. Diagnosing potassium deficiency and maximizing fruit crop productivity. Journal of Better Crops. 89: 29-31.

\section{How to cite this article:}

Deshmukh, U.B., N.K. Mishra and Bharad, S.G. 2018. Effect of Integrated Nutrient Management Practices on Soil Biological Properties in Acid Lime (Citrus aurentifolia Swingle) Orchard. Int.J.Curr.Microbiol.App.Sci. 7(04): 713-717. doi: https://doi.org/10.20546/ijcmas.2018.704.079 